\title{
Organic matter stabilization in soil microaggregates: implications from spatial heterogeneity of organic carbon contents and carbon forms
}

\author{
Johannes Lehmann • James Kinyangi • \\ Dawit Solomon
}

Received: 3 February 2006 / Accepted: 10 October 2006 / Published online: 14 March 2007

(C) Springer Science+Business Media B.V. 2007

\begin{abstract}
This study investigates the spatial distribution of organic carbon (C) in free stable microaggregates (20-250 $\mu \mathrm{m}$; not encapsulated within macroaggregates) from one Inceptisol and two Oxisols in relation to current theories of the mechanisms of their formation. Two-dimensional micro- and nano-scale observations using synchrotron-based Fourier-transform infrared (FTIR) and near-edge X-ray absorption fine structure (NEXAFS) spectroscopy yielded maps of the distribution of $\mathrm{C}$ amounts and chemical forms. Carbon deposits were unevenly distributed within microaggregates and did not show any discernable gradients between interior and exterior of aggregates. Rather, $\mathrm{C}$ deposits appeared to be patchy within the microaggregates. In contrast to the random location of $\mathrm{C}$, there were micronscale patterns in the spatial distribution of aliphatic C-H $\left(2922 \mathrm{~cm}^{-1}\right)$, aromatic $\mathrm{C}=\mathrm{C}$ and $\mathrm{N}-\mathrm{H}$ $\left(1589 \mathrm{~cm}^{-1}\right)$ and polysaccharide $\mathrm{C}-\mathrm{O}\left(1035 \mathrm{~cm}^{-1}\right)$. Aliphatic $\mathrm{C}$ forms and the ratio of aliphatic $\mathrm{C} /$ aromatic $\mathrm{C}$ were positively correlated $\left(r^{2}\right.$ of $0.66-0.75$ and $0.27-0.59$, respectively) to the amount of $\mathrm{O}-\mathrm{H}$ on kaolinite surfaces
\end{abstract}

J. Lehmann $(\varangle) \cdot J$. Kinyangi $\cdot$ D. Solomon

Department of Crop and Soil Sciences,

College of Agriculture and Life Sciences,

Cornell University, 909 Bradfield Hall,

Ithaca, NY, 14853, USA

e-mail: CL273@cornell.edu $\left(3695 \mathrm{~cm}^{-1}\right)$, pointing at a strong role for organomineral interactions in $\mathrm{C}$ stabilization within microaggregates and at a possible role for molecules containing aliphatic $\mathrm{C}-\mathrm{H}$ groups in such interactions. This empirical relationship was supported by nanometer-scale observations using NEXAFS which showed that the organic matter in coatings on mineral surfaces had more aliphatic and carboxylic $\mathrm{C}$ with spectral characteristics resembling microbial metabolites than the organic matter of the entire microaggregate. Our observations thus support models of $\mathrm{C}$ stabilization in which the initially dominant process is adsorption of organics on mineral surfaces rather than occlusion of organic debris by adhering clay particles.

Keywords Aliphatic C, Aromatic C · FTIR Minerals $\cdot$ NEXAFS $\cdot$ Free microaggregates

\section{Introduction}

Soil organic matter (SOM) constitutes the largest pool of organic C on the Earth's surface (IPCC 2001; Blanco-Canqui and Lal 2004) and exerts strong control on greenhouse gas emissions (Schimel et al. 2001; Lal 2003), C sequestration (Lal 2004), soil fertility and plant productivity, and filtration of water during its passage through soil (Stevenson and Cole 1999). Most organic matter enters the soil as readily recognizable plant litter 
and is mineralized within months (Christensen 2001). A small portion, however, may be stabilized through interactions with mineral surfaces for periods up to thousands of years (Schloesing 1902; Golchin et al. 1994a; Sollins et al. 1996; Trumbore 2000; Six et al. 2004). Stabilization of SOM is therefore of great importance for biogeochemical cycles on an ecosystem and global scale, yet these stabilization mechanisms are still poorly understood.

Microaggregates are considered to be the repository of the most stable $\mathrm{C}$ pool in soils (Edwards and Bremner 1967; Tisdall and Oades 1982; Six et al. 2000) and the largest proportion of $\mathrm{C}$ input into stable soil organic matter pools was found in microaggregates (Kong et al. 2005). Two major mechanisms have been postulated to explain formation of microaggregates and the consequent long-term stabilization of SOM. Following upon earlier findings (Schloesing 1902; Sideri 1936), Emerson (1959) and Edwards and Bremner (1967) proposed that organo-mineral microaggregates $(20-250 \mu \mathrm{m})$ form by interactions of polyvalent metals and organic ligands with mineral surfaces. The nature and binding strength of organo-mineral interactions depend on the type (Kaiser et al. 2002) and surface area of the mineral particles (Guggenberger and Kaiser 2003). Others argue for a mechanism in which microaggregates form when organic debris become surrounded by fine mineral particles (Tisdall and Oades 1982; Six et al. 1998; Cambardella and Elliot 1993; Golchin et al. 1994b; Jastrow 1996). These two processes of microaggregate formation, organo-mineral interactions and occlusion of debris by clay particles, are not mutually exclusive. But to what extent do they contribute to $\mathrm{C}$ stabilization?

Here we applied synchrotron-based microspectroscopy, using x-ray focusing optics (Jacobsen et al. 2000) coupled with C K-edge signal acquisition (NEXAFS) and Fourier-transform infrared (FTIR) spectroscopy (Miller et al. 2002), to map $\mathrm{C}$ contents and forms at a spatial resolution of $0.05-5 \mu \mathrm{m}$. The FTIR mapping also shows the location of organic $\mathrm{C}$ forms in relation to mineral surfaces, thus providing direct evidence for the relative importance of the two modes of microaggregate formation. Using an improved soil sectioning technique, we were able to investigate entire microaggregates for the first time, significantly expanding our earlier NEXAFS experiments (Kinyangi et al. 2006) and enabling use of FTIR in transmission mode at high spatial resolution. Kinyangi et al. (2006) found that organic C forms close to the aggregate surface differed from those in the aggregate interior, as did organic $\mathrm{C}$ forms on mineral surfaces versus those in pores. Whether such differences affect the distribution of $\mathrm{C}$ forms across entire microaggregates was not clear. The location of the organic matter within the aggregate and its chemical form can then be used to make inferences about the mechanism of $\mathrm{C}$ stabilization in microaggregates. The objective of this study was to map the spatial distribution of $\mathrm{C}$ and its chemical forms within microaggregates. The results are discussed in relation to theories supporting the formation of microaggregates by organo-mineral interactions vs. occlusion of organic debris by clay particles.

\section{Materials and methods}

Site information

Soils were obtained from McGowen forest in Tompkins County, Upstate New York $\left(42^{\circ} 26^{\prime} 44^{\prime \prime} \mathrm{N}\right.$ and $\left.76^{\circ} 27^{\prime} 2^{\prime \prime} \mathrm{W}\right)$ in the USA; Nandi forest $\left(00^{\circ} 04^{\prime} 30^{\prime \prime} \mathrm{N}\right.$ and $\left.34^{\circ} 58^{\prime} 34^{\prime \prime} \mathrm{E}\right)$ in Western Kenya; and Lago Grande forest south of Manaus (03 $13^{\prime} 40^{\prime \prime} \mathrm{S}$ and 60 $\left.16^{\prime} 04^{\prime \prime} \mathrm{W}\right)$ in Brazil. McGowan is a virtually undisturbed northern mixed mesophytic forest (Gauch and Stone 1979; Doyle and Doyle 1988). The upper canopy is dominated by Liriodendron tulipifera (L.), Magnolia acuminata (L.), Pinus strobus (L.), Quercus rubra (L.), Carya ovata (K. Koch), Carya glabra (Sweet), Fraxinus americana (L.) and Fraxinus nigra (Marsh.); while the lower story is composed of Acer rubrum (L.), Acer saccharum (Marsh.) and Carpinus caroliniana (Walter) (E. Stone unpublished data). Elevation is about $280 \mathrm{~m}$ a.s.l., with a mean annual temperature of $8.0^{\circ} \mathrm{C}$ and precipitation of $924 \mathrm{~mm}$. Soils, formed in stratified silty deposits of glacial lake origins, are moderately well drained, sandy loam in texture, and are classified as Dystrochrepts (USDA 1999) 
Table 1 Selected climate and soil properties of the studied sites

\begin{tabular}{|c|c|c|c|c|c|c|c|c|c|c|c|c|}
\hline Site & Soil type & Country & $\begin{array}{l}\mathrm{MAP}^{\mathrm{a}} \\
(\mathrm{mm})\end{array}$ & $\begin{array}{l}\text { Sand } \\
(\%)\end{array}$ & $\begin{array}{l}\text { Silt } \\
(\%)\end{array}$ & $\begin{array}{l}\text { Clay } \\
(\%)\end{array}$ & $\begin{array}{l}\mathrm{pH} \\
\mathrm{H}_{2} \mathrm{O}\end{array}$ & $\mathrm{KCl}$ & $\mathrm{C}\left(\mathrm{mg} \mathrm{g}^{-1}\right)$ & $\mathrm{N}\left(\mathrm{mg} \mathrm{g}^{-1}\right)$ & $\mathrm{C} / \mathrm{N}$ & $\begin{array}{l}\mathrm{CEC}^{\mathrm{b}} \\
\mathrm{cmol} \mathrm{kg}^{-1} \text { soil }\end{array}$ \\
\hline McGowan & Dystrochrept & USA & 924 & 17.0 & 70.0 & 13.0 & 6.1 & 5.2 & 34.0 & 2.6 & 13.1 & 11.5 \\
\hline Nandi & Hapludox & Kenya & 2000 & 65.0 & 22.0 & 13.0 & 6.5 & 5.9 & 95.1 & 9.5 & 10.1 & 12.0 \\
\hline Lago Grande & Hapludox & Brazil & 2500 & 69.0 & 4.0 & 27.0 & 4.2 & 3.5 & 17.5 & 1.3 & 14.0 & 59.2 \\
\hline
\end{tabular}

${ }^{a}$ Mean annual precipitation

b Potential cation exchange capacity

(Table 1). The Nandi highland forest in western Kenya is the eastern-most remnant of the once contiguous Guineo-Congolian rainforest and is among the last remnants of pristine tropical rainforest in this intensely cultivated region. Nandi forest is composed of Guineo-Congolian species including Aningeria altissima (A. Chev.), Milicia excelsa (Welw., C.C. Berg), Antiaris toxicaria (Lesch) and Chrysophyllum albidum (G. Don). Montane-forest species are also present including Olea capensis (L.) and Croton megalocarpus (Hutchinson). The Nandi site is located $2000 \mathrm{~m}$ a.s.l. with a mean annual temperature of $19.0^{\circ} \mathrm{C}$ and precipitation of $2000 \mathrm{~mm}$. Soils are welldrained, extremely deep dark reddish brown soils with friable clay and thick organic-rich topsoils developed principally from biotite-gneiss parent material. The soils are classified as Hapludoxes (USDA 1999). The Lago Grande forest site is at about $45 \mathrm{~m}$ a.s.l., with a mean annual precipitation of $2500 \mathrm{~mm}$ and temperature of $26.6^{\circ} \mathrm{C}$. Soils, derived from Tertiary sediments, are welldrained, yellow in color and clayey textured. They are classified as Hapludoxes (USDA 1999). The forest is large stature with high species diversity and a sparse herbaceous cover. The most frequent species are Chrysophyllum amazonicum (T.D. Penn.), Chrysophyllum sanguinolentum (Pierre, Baehni), Crepidospermum rhoifolium (Benth., Triana \& Panch), Anacardium parvifolium (Ducke), Ambelania acida (Aubl.), Dinizia excelsa (Ducke), Sloanea sinemariensis (Aublet), Bocageopsis multiflora (Mart., R.E. Fr.) and Bertholletia excelsa (Humb. \& Bonpl) (de Oliveira and Mori 1999). The Lago Grande forest is also particularly rich in epiphytes such as Philodendron spp, Heteropsis spp and Anthurium spp and stranglers of Ficus spp.
Soil sampling and analyses

Samples for NEXAFS were collected at McGowen forest in March 2005. After removing the litter layer, we froze the topsoil with liquid nitrogen, then carved $10 \mathrm{~cm} \times 10 \mathrm{~cm}$ intact blocks which were stored at $4^{\circ} \mathrm{C}$ overnight. NEXAFS samples from the Nandi and Lago Grande sites, and samples from the McGowen site used for other analyses, were collected by taking six to nine $200 \mathrm{~cm}^{3}$ cores from the upper $10 \mathrm{~cm}$ of the soil, which were later composited into one sample per plot. The composite samples were then sieved to $2 \mathrm{~mm}$ and homogenized.

Soil texture was determined using the pipette method with $20 \mathrm{~g}$ dry soil dispersed in $1000 \mathrm{ml}$ $10 \%$ Calgon solution, separated by sedimentation for different periods of time, dried, and weighed (Gee and Orr 2002). The $\mathrm{pH}$ in $\mathrm{H}_{2} \mathrm{O}$ and in $\mathrm{KCl}$ was determined in a 1:2.5 soil:water (w/v) suspension. Aliquots were finely ground with a Mixer Mill (MM301, Retsch, Germany) and organic C and total $\mathrm{N}$ contents determined using a Europa ANCA GSL analyzer (PDZEuropa, Crewe, England). The potential CEC was measured by twice saturating the exchange sites of $1 \mathrm{~g}$ soil with $40 \mathrm{ml} 1 \mathrm{M}$ ammonium acetate at $\mathrm{pH} 7$, then displacing the adsorbed ammonium ions with $2 \mathrm{M}$ $\mathrm{KCl}$. The ammonium was measured with a segmented flow analyzer (Technicon Auto Analyzer, Chauncey, CT, USA).

Sample preparation for NEXAFS and FTIR spectroscopy

Intact microaggregates $(20-250 \mu \mathrm{m})$ were picked from the soil samples (after slight thawing of the McGowan forest sample cores at room tempera- 
ture) using super tweezers (N5, Dumont, Montignez, Switzerland) under a $30 \times$ light microscope. Only those microaggregates that were easily separated from the soil without breakage and maintained visibly round edges (termed here "free stable microaggregates") were selected. After 4060 microaggregates were obtained from each soil, we selected 5-10 typical examples for spectroscopic analyses. The selected microaggregates were sprinkled on a Whatman GF/A filter, mounted onto a sieve and fixed to a chimney funnel that transferred warm mist from a humidifier filled with ultrapure water. After eighteen hours of continuous misting, the microaggregates were considered to be water saturated. Excess droplets on the filter were drained after which microaggregates were selected and frozen at $-20^{\circ} \mathrm{C}$ and directly sectioned without embedding in liquid sulfur (Lehmann et al. 2005; Kinyangi et al. 2006). Thin sections $(300-600 \mathrm{~nm})$ were cut at $-55^{\circ} \mathrm{C}$ using an ultramicrotome with a diamond knife (MS9859 Ultra $45^{\circ} \mathrm{C}$, Diatome Ltd., Biel, Switzerland) at a cutting speed of $0.3 \sim 1.2 \mathrm{~mm} \mathrm{sec}^{-1}$ (angle of $6^{\circ}$ ). Sections were transferred to $\mathrm{Cu}$ grids (carbon free, $200 \mathrm{mesh}$, silicon monoxide No. 53002, Ladd Research, Williston, VT) and air-dried.

\section{STXM and C (1s) NEXAFS data collection} and analysis

Coupled with STXM, NEXAFS images were recorded at different energies below and above the $\mathrm{C}$ absorption $\mathrm{K}$ edge $(284.3 \mathrm{eV})$ at the X1-A end station of the National Synchrotron Light Source (NSLS) at Brookhaven National Laboratory. The synchrotron beam delivers a flux of $\sim 10^{7}$ photons $\mathrm{s}^{-1}$, with an energy bandwidth of about $0.1 \mathrm{eV}$ for soft X-rays. Due to difficulties in maintaining the sample at the focal point for submicrometer-sized areas, direct recording of NEXAFS data by simple scanning of the incident radiation energy at a fixed sample position was not possible. Therefore, a Fresnel zone-plate focus was used and stack images were recorded (Rothe et al. 2000). Scanning was done at increments of $0.3 \mathrm{eV}$ (dwell time $1 \mathrm{msec}$ ) for the energy range from 280 to $282.5 \mathrm{eV}$, at $0.1 \mathrm{eV}$ up to $292 \mathrm{eV}$ (dwell time $2 \mathrm{msec}$ ), and at $0.3 \mathrm{eV}$ up to
$310 \mathrm{eV}$ (dwell time $3 \mathrm{msec}$ ). Entire aggregates were scanned at a distance of $500 \mathrm{~nm}$ between individual measurement points $(50 \mathrm{~nm}$ for areas within aggregates) with a pixel size of $50 \mathrm{~nm}$. Individual images scanned across all energy levels were stacked (Stack-Analyze 2.6 software, C. Jacobsen, SUNY Stony Brook; built on IDL 6.1 software, Research Systems Inc., Boulder, CO), then aligned mathematically (using $290 \mathrm{eV}$ as a reference) to correct for mechanical shift of the sample stage out of the focal point $(<0.3$ pixels).

Carbon amounts were mapped within aggregates by subtracting spectral regions below the $\mathrm{C}$ $\mathrm{K}$-edge at $280.5-282.5 \mathrm{eV}$ from regions above the C K-edge at 290-292 eV. After defining a background correction area $\left(\mathrm{I}_{0}\right)$ and orthogonalizing and noise-filtering the data, principal component and cluster analyses (PCA_GUI 1.0, Lerotic et al. 2004) were used to identify sample regions with similar spectra. From 2 to 4 components and 20 clusters were used based on the eigenvalues, eigenimages, and eigenspectra (Beauchemin et al. 2002; Lerotic et al. 2005). The goal was to select components due to systematic variations of spectral signals from pixel to pixel and to discard random fluctuations of signal beyond which noise effects will occur. A singular value decomposition (SVD) procedure was used to obtain target maps and associated target spectra. For comparison, spectra for entire aggregates were obtained using Stack-Analyze 2.6 software.

FTIR data collection and analysis

Fourier Transform Infrared (FTIR) analysis was done at the U10B beamline of the NSLS facility at Brookhaven National Laboratory. This beamline is equipped with a Spectra Tech Continuum IR microscope fitted with $32 \times$ transmission/reflection and FTIR step-scan spectrophotometer (Nicolet Magna 860, Thermo Nicolet Corporation Wisconsin, USA) using a KBr beam splitter and mercurycadmium-telluride detector with $500-4000 \mathrm{~cm}^{-1}$ wave-number range and $1.0 \mathrm{~cm}^{-1}$ spectral resolution. Spectral maps of aggregates were recorded with a $7-\mu \mathrm{m}$ aperture size and a step size of $6 \mu \mathrm{m}$ from 4000 to $650 \mathrm{~cm}^{-1}$ at spectral intervals of $4 \mathrm{~cm}^{-1}$. Each spectrum was composed of 256 scans added before Fourier transformation. 
Spectral maps were processed using Omnic 7.1 (Thermo Electron Corp., Waltham, MA). After cropping to a spectral region from 4000 to $800 \mathrm{~cm}^{-1}$, and normalization and automatic baseline correction, map profiles were created for peak heights at $3687,3620,2922,1589$, and $1035 \mathrm{~cm}^{-1}$. The peak position at $3695 \mathrm{~cm}^{-1}$ corresponds to stretching vibrations of surface $\mathrm{O}-\mathrm{H}$ groups of kaolinite for the two studied Oxisols (Filip et al. 1988; Ledoux and White 1964), at $3620 \mathrm{~cm}^{-1}$ to illite for the studied Inceptisol (Sucha et al. 1998), at $2922 \mathrm{~cm}^{-1}$ to $\mathrm{C}-\mathrm{H}$ stretching vibrations in aliphatic biopolymers (Haberhauer et al. 1998; Baddi et al. 2003), at $1589 \mathrm{~cm}^{-1}$ to $\mathrm{C}=\mathrm{C}$ stretching of aromatic $\mathrm{C}$ or $\mathrm{N}-\mathrm{H}$ deformations (Filip and Kubát 2003), and at $1035 \mathrm{~cm}^{-1}$ to C-O stretching vibrations of polysaccharide C (Haberhauer et al. 1998; Solomon et al. 2005). Peaks around $1035 \mathrm{~cm}^{-1}$, however, can also be due to $\mathrm{Si}-\mathrm{O}$ vibrations in some clay minerals and can only be attributed to $\mathrm{C}-\mathrm{O}$ when found in conjunction with low intensities at wave numbers above $3600 \mathrm{~cm}^{-1}$ (see below).

\section{Statistical analyses}

Linear regressions between peak heights obtained by FTIR spectroscopy were done using Statistica 5.1 (StatSoft, Hamburg, Germany).

\section{Results and discussion}

Distribution of carbon in free stable microaggregates

Total organic $\mathrm{C}$ was found to be unevenly distributed within microaggregates obtained from the three sites (Fig. 1), with no consistent variation from microaggregate surfaces to interiors. Distinct $\mathrm{C}$ deposits were observed close to the surface as well as in the interior of microaggregates. These organic $\mathrm{C}$-rich areas located close to the aggregate surfaces were still separated from pore space by minerals (McGowen and Lago Grande forests, Fig. 2) or by occlusion within small pores that are not accessible to microorganisms (Nandi forest, Fig. 2). Therefore, very little organic matter appeared to be located on open surfaces of the studied microaggregates. In contrast, Amelung et al. (2002), using sputtering with an Ar-ion gun followed by XPS analysis to study microaggregates slightly larger than $53 \mu \mathrm{m}$ obtained from a Mollisol, showed that most of the organic C was located on the microaggregate surfaces. Also Skjemstad et al. (1993) concluded from UV oxidation of similarly sized microaggregates that only 23 to $36 \%$ of the $\mathrm{C}$ was contained in physically protected areas, presumably within the aggregates. These techniques may have captured a portion of interior regions of microaggregates which also in our images were shown to be $\mathrm{C}$ rich. The lack of an organic core in our images contrasts with the theory that microaggregates may form around organic debris (Tisdall and Oades 1982; Six et al. 1998; Cambardella and Elliot 1993; Golchin et al. 1994b; Jastrow 1996).

Distribution of carbon forms in free stable microaggregates

While the distribution of total $\mathrm{C}$ appeared to be random, certain $\mathrm{C}$ forms (but not all) showed clearly discernable spatial patterns. For the two Oxisols, aliphatic $\mathrm{C}$ appeared to have a spatial distribution directly correlated with that of kaolinite O-H (at $3695 \mathrm{~cm}^{-1}$; Fig. 4), whereas aromatic $\mathrm{C}=\mathrm{C}$ bonds and $\mathrm{N}-\mathrm{H}$ deformations $\left(1589 \mathrm{~cm}^{-1}\right)$ showed an inverse correlation with kaolinite $\mathrm{O}-\mathrm{H}$. These visual observations were confirmed by correlation analyses (Fig. 5). The FTIR-based maps of organic C forms (Fig. 3), also indicated that the patterns of polysaccharide $\mathrm{C}(\mathrm{C}-\mathrm{O}$ bonds at $1035 \mathrm{~cm}^{-1}$; Fig. 4$)$, aromatic $\mathrm{C}(\mathrm{C}=\mathrm{C}$ bonds and $\mathrm{N}-\mathrm{H}$ deformations assigned to a peak position at $1589 \mathrm{~cm}^{-1}$; Fig. 4) and aliphatic $\mathrm{C}$ at $2922 \mathrm{~cm}^{-1}$ (C-H stretching vibrations; Fig. 4) were different and spatially unrelated.

For the McGowen site, the $\mathrm{O}-\mathrm{H}$ stretching vibrations at $3620 \mathrm{~cm}^{-1}$ (Fig. 4) most likely originated from illites (Sucha et al. 1998) and correlated well with both aliphatic $\left(r^{2}=0.51\right)$ and aromatic $\mathrm{C}\left(r^{2}=0.65 ; \mathrm{N}=34\right)$. Correlations with carbohydrate $\mathrm{C}-\mathrm{O}$ were significant $\left(r^{2}=0.42\right)$ but ambiguous for this soil as the illitic Si-O signal most likely overlapped with the $\mathrm{C}-\mathrm{O}$ stretching vibrations at $1035 \mathrm{~cm}^{-1}$. It should be kept in mind, however, that the nature of the clay-bound 

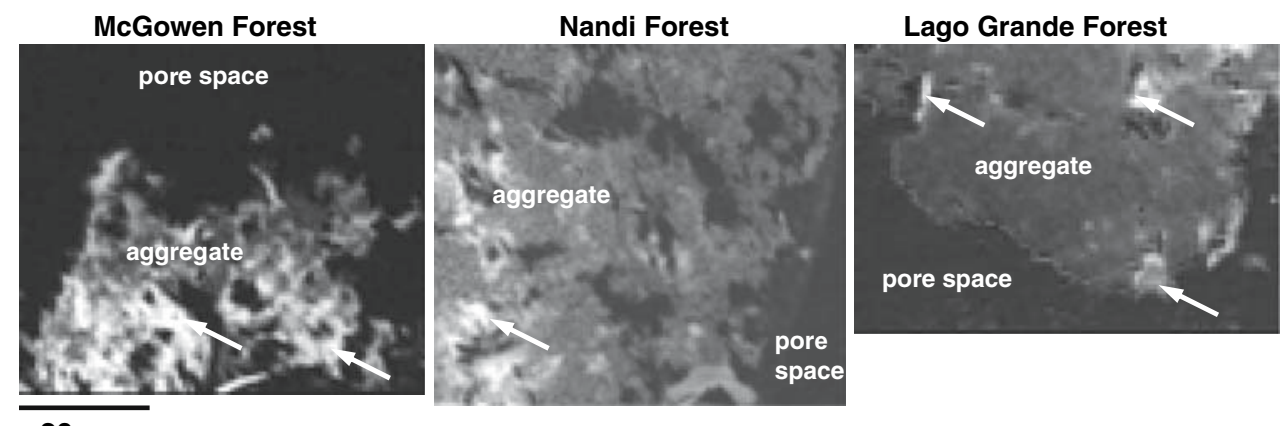

$20 \mu \mathrm{m}$

Fig. 1 Carbon distribution in free stable microaggregates from three soils using C (1s) NEXAFS (0.5- $\mu \mathrm{m}$ resolution); white arrows point at regions of high $\mathrm{C}$ content shown as white areas
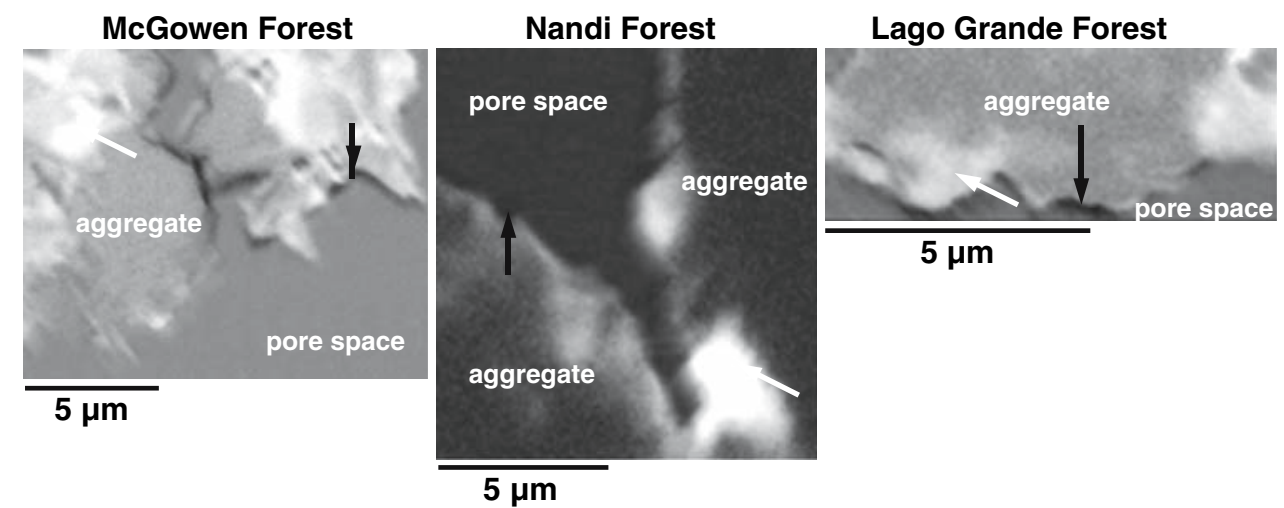

Fig. 2 Carbon distribution near microaggregate surfaces using C (1s) NEXAFS (0.05- $\mu \mathrm{m}$ resolution); white arrows point at regions of high $\mathrm{C}$ content shown as white areas;

organic matter may vary with clay surface chemistry (Greenland 1965; Jardine et al. 1989; Golchin et al. 1995; Lichtfouse et al. 1998; Kahle et al. 2003; Zimmerman et al. 2004). We were not successful in exploring other clay minerals or amorphous oxides that may have a very strong control on $\mathrm{C}$ stabilization through surface interactions (Mikutta et al. 2006). This should be done in future experiments capitalizing on spectral areas with wave numbers below $800 \mathrm{~cm}^{-1}$.

Aliphatic $\mathrm{C}$ and non-polar interactions have been previously recognized as important in organo-mineral interactions and microaggregation (Wershaw and Pinckney 1980; Jardine et al. 1989; Wershaw et al. 1996; Kleber et al. this volume). Using FTIR Skjemstad et al. (1993) found more aliphatic $\mathrm{C}$ in silt-sized aggregate fractions $(2-20 \mu \mathrm{m})$ than in smaller structural units $(<2 \mu \mathrm{m})$, suggesting a role for aliphatic compounds black arrows point at dark areas of high absorbance consisting of clay coatings

in microaggregate formation. Moreover, aliphatic $\mathrm{C}$ has been shown to be more abundant in clay-size than in coarser particles as determined by nuclear magnetic resonance (NMR) spectroscopy (Oades 1988), spectrophotometry of humic-acid fractions (Anderson et al. 1981), and fatty-acid extracts followed by gas chromatography (Jandl et al. 2004).

The empirical correlation between $\mathrm{C}$ forms and surface hydroxyls of kaolinite determined by FTIR (Fig. 5) was further examined on a nanometer scale by directly identifying the chemical forms of the organic matter that coated mineral surfaces using NEXAFS maps (Fig. 6). These maps showed that the clay-bound SOM was richer in aliphatic $\mathrm{C}(287.2 \mathrm{eV})$ and carboxylic $\mathrm{C}$ $(288.6 \mathrm{eV})$ than the SOM averaged over the entire aggregate cross-section (Fig. 6). Similarly, Kinyangi et al. (2006) using C K-edge NEXAFS found organic coatings in microaggregates to be 




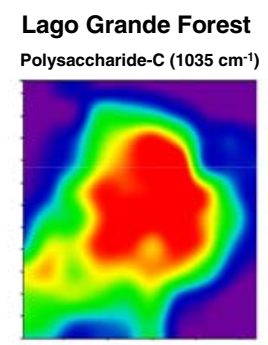

Aliphatic-C $\left(2922 \mathrm{~cm}^{-1}\right)$

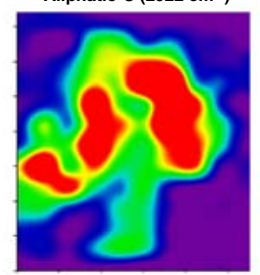

Visible image

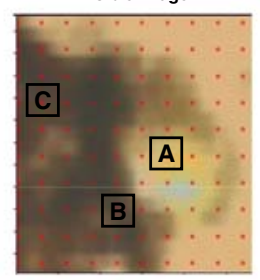

Aromatic-C $\left(1589 \mathrm{~cm}^{-1}\right)$



Clay minerals $\left(3695 \mathrm{~cm}^{-1}\right)$

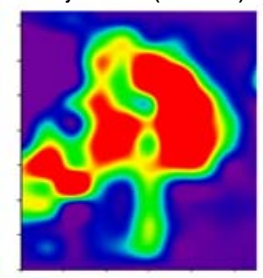

$\overline{10 \mu \mathrm{m}}$

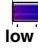

w
McGowen Forest

Polysaccharide-C $\left(1035 \mathrm{~cm}^{-1}\right)$

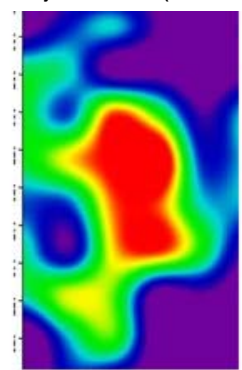

Aliphatic-C (2922 cm-1)

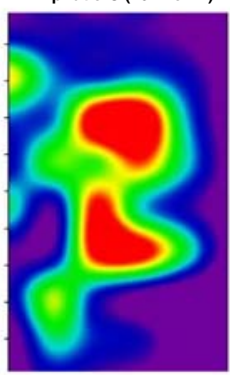

Visible image

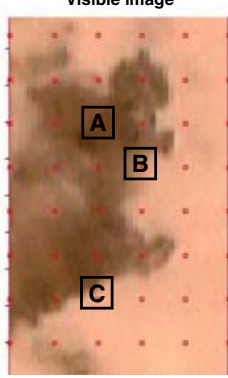

Aromatic-C $\left(1589 \mathrm{~cm}^{-1}\right)$

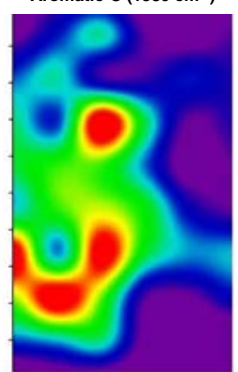

Clay minerals $\left(3620 \mathrm{~cm}^{-1}\right)$

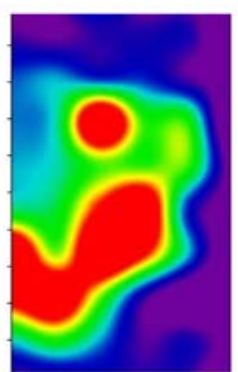

$10 \mu \mathrm{m}$

low high
Fig. 3 Distribution of polysaccharide $C\left(1035 \mathrm{~cm}^{-1}\right)$, aromatic $\mathrm{C}\left(1589 \mathrm{~cm}^{-1}\right)$, aliphatic $\mathrm{C}\left(2922 \mathrm{~cm}^{-1}\right)$ and kaolinite $\mathrm{O}-\mathrm{H}\left(3687 \mathrm{~cm}^{-1}\right)$ in aggregates from Nandi (Kenya), Lago Grande (Brazil), and McGowen (USA) forests using FTIR

richer in carboxylic $\mathrm{C}$, and poorer in aromatic $\mathrm{C}$, than organic debris in pores. Such associations between carboxylic-C groups and clay surfaces confirm several earlier reports (Emerson 1955; Edwards and Bremner 1967; Oades 1988).

The chemical signature of these coatings, mainly aliphatic and carboxylic with minor amounts of aromatic $\mathrm{C}$, resemble NEXAFS spectra of cells in bacterial biofilms (Lawrence et al. 2003) and of isolated bacteria and fungi (Liang et al. 2006) suggesting that the coatings could be mainly microbial structural metabolites or debris. The significant spatial relationship between clay particles and microbially derived coatings, but not plant debris, points at the importance of spectroscopy (5- $\mu \mathrm{m}$ resolution); the color scale is a relative scale for each peak height and does not allow quantitative comparisons between peaks

organo-mineral interactions for the formation of microaggregates.

The precise nature of the organic coatings remains elusive from our analysis and requires targeted analyses using $\mathrm{O}$ and $\mathrm{N}$ K-edge NEXAFS. The conspicuous absence of a relationship between kaolinite $\mathrm{O}-\mathrm{H}$ and polysaccharide $\mathrm{C}-\mathrm{O}$ (at $1035 \mathrm{~cm}^{-1}$ ) using FTIR (Figs. 3 and 4) is in apparent contrast to conclusions drawn from a variety of experiments, some of which date back well into the last century, in which microbial polysaccharides are seen to intimately associate with clays (Martin 1945; Geoghegan and Brian 1948; Greenland et al. 1961; Martin 1971; Tisdall and Oades 1988; Foster 1981, 1988; Tiessen and 

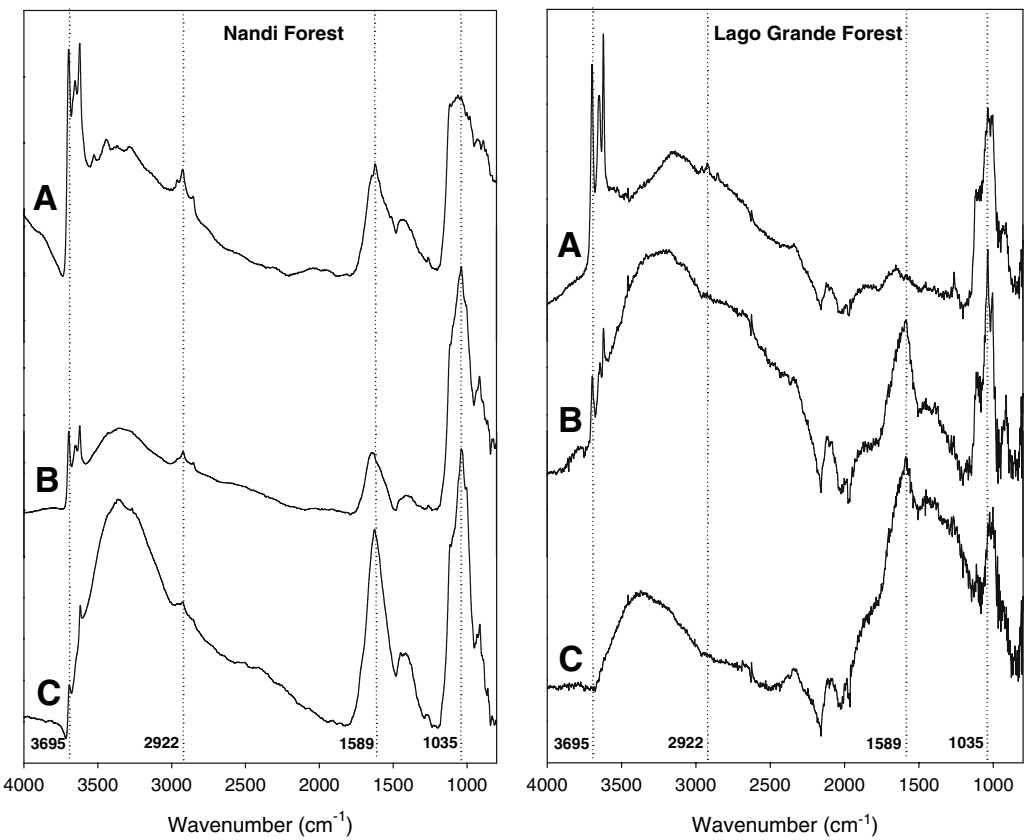

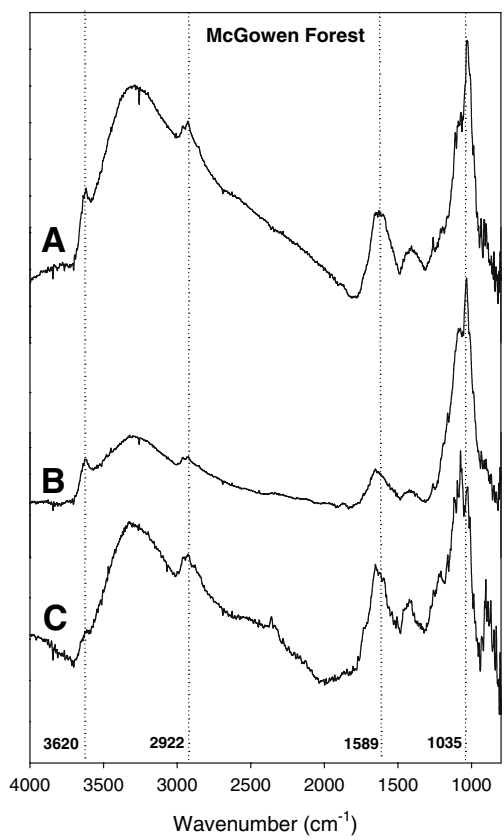

Fig. 4 Representative FTIR spectra of locations within free microaggregates with large (A), medium (B), and small (C) amounts of kaolinite $\mathrm{O}-\mathrm{H}$ of clay minerals (indicated by the peak intensity at $3687 \mathrm{~cm}^{-1}$ ); locations of spectra are identified with boxes in Fig. 3
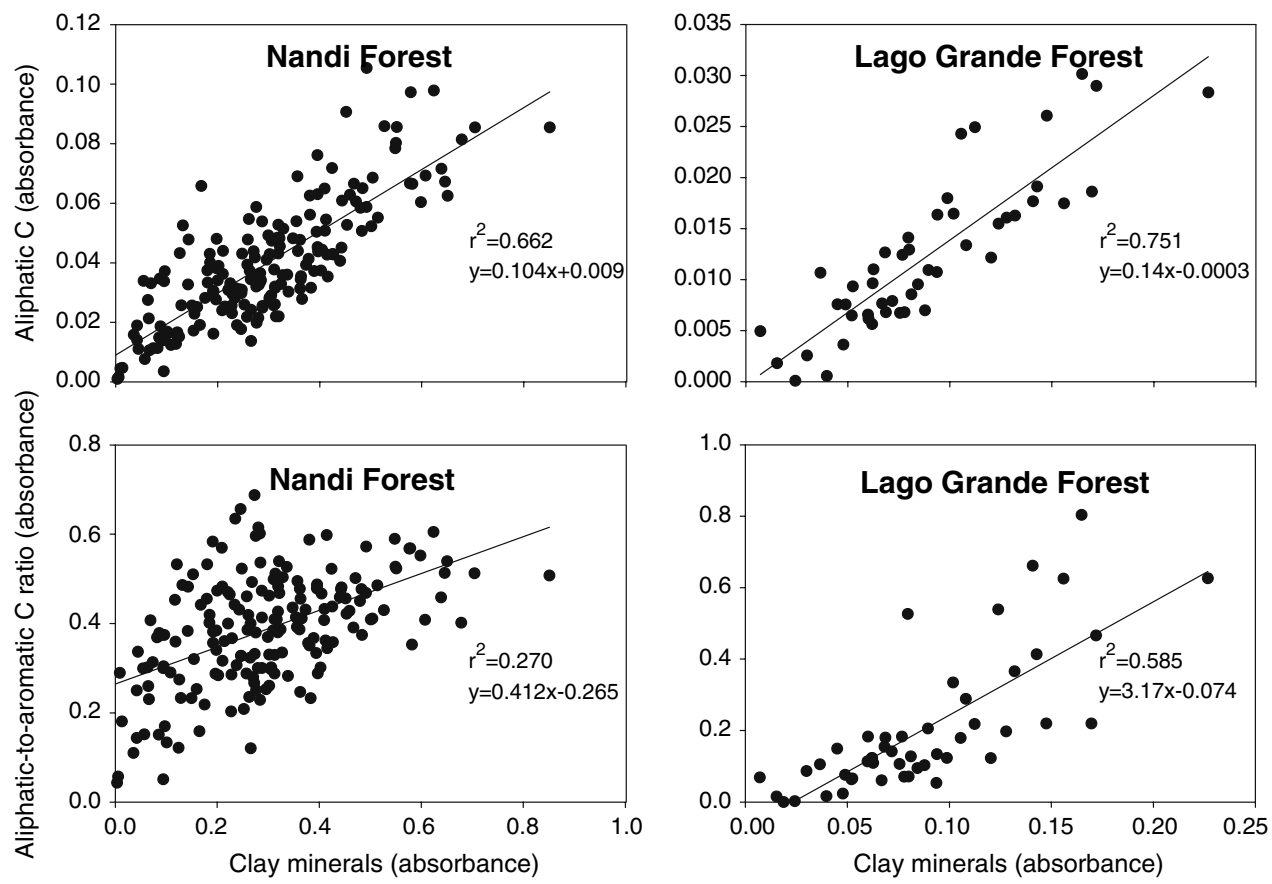

Fig. 5 Relationship between the amount of clay (absorbance at $3695 \mathrm{~cm}^{-1}$ ) and either aliphatic C (absorbance at $2922 \mathrm{~cm}^{-1}$ ) or the ratio of aliphatic (absorbance at $2922 \mathrm{~cm}^{-1}$ ) to aromatic C (absorbance at $1589 \mathrm{~cm}^{-1}$ )

( $\mathrm{N}=185$ and 55 for Nandi and Lago Grande forests, respectively); the positive relationship between clay and the ratio of aliphatic to aromatic $\mathrm{C}$ argues against artifacts due to different densities within the aggregate 

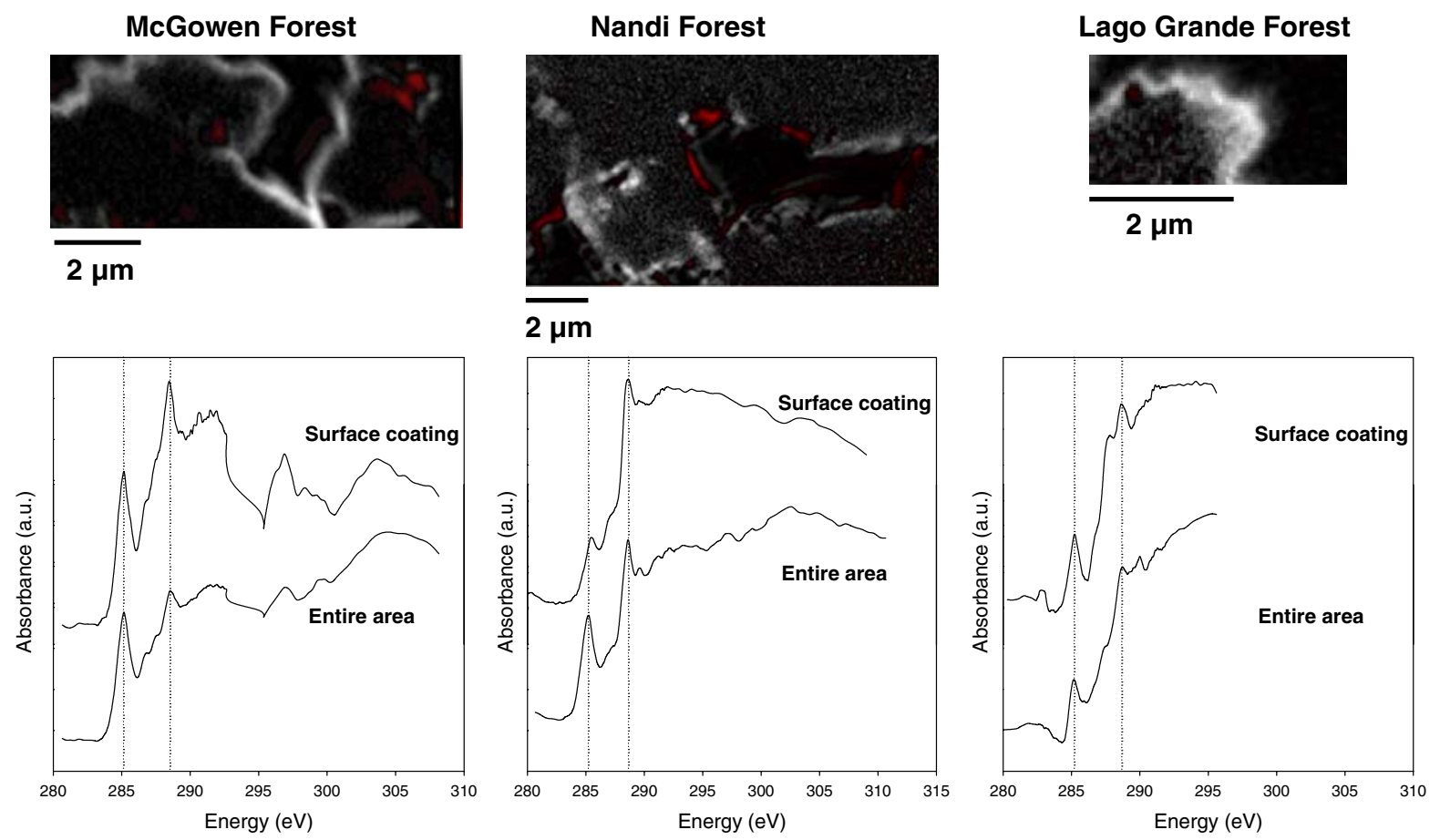

Fig. 6 Carbon distribution (maps) and forms (graphs) on mineral surfaces within free microaggregates using C (1s) NEXAFS $(0.05 \mu \mathrm{m}$ resolution $)$; white areas in images indicate regions that are best described with the spectrum

Stewart 1988; Guggenberger et al. 1994; Solomon et al. 2002). However, it can not be excluded that the $\mathrm{C}-\mathrm{O}$ stretching vibrations determined by FTIR are either a minor component of those organic compounds that are interacting with mineral surfaces or are masked by interferences from $\mathrm{Si}-\mathrm{O}$ of minerals at $1035 \mathrm{~cm}^{-1}$. Other explanations for the absence of a spatial association between kaolinite and polysaccharides may include that polysaccharides (i) do not have a persistent (as proposed by Tisdall and Oades 1982) but rather a transient role in $\mathrm{C}$ stabilization in microaggregates, (ii) are correlated with stabilization but do not cause stabilization and therefore increase only as a result of $\mathrm{C}$ stabilization, or (iii) constitute precursors of substances that provide long-term binding and stabilization.

Implications for organic matter stabilization in microaggregates

Our high-resolution observations of $\mathrm{C}$ forms in free stable microaggregates by synchrotron-based labeled "surface coating"; the spectrum for the entire aggregate is shown for comparison and energy levels at $285.2 \mathrm{eV}$ and $288.6 \mathrm{eV}$ are indicated by vertical dashed lines

spectroscopy warrant a fresh look at the published theories of the nature of this stable $\mathrm{C}$ pool and how organic matter is stabilized in microaggregates. Particulate organic debris were found in stable microaggregates (Six et al. 2000, 2002) and microbial debris can be encrusted with minerals (Tisdall and Oades 1982). Such observations would support the view of physical occlusion as an important mechanism of stabilization and of location inside a microaggregate as the key to ensure organic matter stability.

Our results from C (1s) NEXAFS maps rather suggest that the genesis of a microaggregate begins with the formation of bonds between minerals and organic matter with minimal protection by aggregation at its inception (stage 2 in Fig. 7). This proposal expands earlier hypotheses by emphasizing the importance of organo-mineral interaction as the initiation of stabilization and key to stable C, whereas models proposed by Emerson (1959), Tisdall and Oades (1982), Beare et al. (1994), and Six et al. (1998 2000) start this process with an encapsulation of organic matter 




Fig. 7 Conceptual model of the formation of free stable microaggregates by first the development of an organic coating on a clay minerals and then the physical occlusion of the organic coating by a second mineral

between minerals concurrent with its attachment to mineral surfaces.

The present study also emphasizes the importance of microbial metabolites for the formation of stable microaggregates rather than plant debris as nuclei for microaggregate formation (Tiessen and Stewart 1988; Oades and Waters 1991; Beare et al. 1994). Such a view agrees with observations of the intimate spatial association between microbial metabolites and clays using electron microscopy (Ladd et al. 1993) and their strong adsorption to clay surfaces (Chenu and Stotzky 2002; Mikutta et al. 2006). The micro-aggregation as a result of organo-mineral interactions then helps protect the organic matter coatings themselves as well as any intra-aggregate organic debris through physical occlusion in pores (Mayer and Xing 2001; Kaiser and Guggenberger 2003; Mayer et al. 2004; Mikutta et al. 2004; Kinyangi et al. 2006) (Fig. 7). A causal relationship between organo-mineral interactions and physical occlusion may be important when developing management systems designed to improve C stabilization. Greater production of microbial metabolites would then be expected to promote not just aggregation, as has been known for some time (Waksman and Martin 1939), but also C stabilization in microaggregates,

The model outlined here is also in accordance with observations that microaggregates form via different processes and are more stable than macroaggregates (Tisdall and Oades 1982; Elliott and Coleman 1988; Six et al. 2000). It would also explain why large macroaggregates (2-9 mm) show gradients of increasing $\mathrm{C}$ content from surface to interior (Santos et al. 1997; Horn and Smucker 2005; Park and Smucker 2005) whereas the microaggregates studied here did not (Fig. 1). This is because in this concept stabilization in microaggregates is initally conferred by strong organo-mineral interactions (Chenu and Stotzky 2002; Mikutta et al. 2006) and not primarily by physical location such as has been proposed for macroaggregates.

To some extent this search for stabilization mechanisms and attributes of stable SOM in microaggregates is a question of scale. Organo-mineral interactions manifest themselves primarily as organic surface coatings on clay particles, which can be considered an aggregate when sandwiched between two clay particles (Fig. 7). From that perspective, one can ask whether the interaction with mineral surfaces or the protection by its location between minerals confers more stability to the organic matter. A spatial distinction of organic matter forms becomes important to distinguish organic coatings that bear very different chemical characteristics than organic debris in pores (Kinyangi et al. 2006) (Table 1).

\section{Conclusions}

Two-dimensional micro- and nano-scale observations of the $\mathrm{C}$ distribution in soil microaggregates have provided new insight into the mechanisms of microaggregate formation and thus stabilization of organic C. They suggest that, at least in the soils studied here, microaggregate formation is initiated mainly by accumulation of organics on clay particle surfaces, not by occlusion of organic debris by clay particles. Our results are the first imaging of two-dimensional in-situ $\mathrm{C}$ maps showing nanometer-scale distributions of organic $\mathrm{C}$ in 
entire microaggregates $<250 \mu \mathrm{m}$. In contrast to published results for macroaggregates, the microaggregates studied here did not show a gradient of $\mathrm{C}$ concentrations between exterior and interior regions, a gradient that would be expected if organic debris formed a core in the microaggregates. On the contrary, organic $\mathrm{C}$ was unevenly distributed within microaggregates with distinct "hotspots" of C deposition. Aliphatic and carboxylic $\mathrm{C}$, but not other $\mathrm{C}$ forms showed a clear pattern of association with clay mineral surfaces. Additional studies are warranted to extend these results to aggregates from soils of a wider range of mineralogies.

Our results suggest that interactions between microbial metabolites and mineral surfaces are important in initiating OM stabilization and that physical occlusion within microaggregates is a secondary stabilization process. Future studies should further exploit $\mathrm{C}, \mathrm{N}$ and $\mathrm{O}$ K-edge NEXAFS to investigate fine-scale binding mechanisms between organic matter and mineral surfaces.

\begin{abstract}
Acknowledgements This project was funded by grants from the National Science Foundation (BCS-0215890, DEB-0425995). NEXAFS spectra were obtained at the National Synchrotron Light Source (NSLS), Brookhaven National Laboratory, at the X-1A1 beamline developed by Janos Kirz and Chris Jacobsen at SUNY Stony Brook (Department of Energy contract DE-FG02-89ER60858 and NSF grants DBI-9605045 and ECS-9510499). The FTIR data were collected at U10B of the NSLS, supported by the U.S. Department of Energy (contract DE-AC02-98CH10886). Many thanks to Lisa Miller and Randy Smith at NSLS for help with FTIR measurements, to Sue Wirick, Chris Jasobsen, and Mirna Lerotic for assistance with the NEXAFS measurements and data analysis, and to Yuanming Zhang and Julia Dathe for invaluable help with sectioning. We are indebted to two anonymous referees for constructive comments on earlier versions of the manuscript.
\end{abstract}

\section{References}

Amelung W, Kaiser K, Kammerer G, Sauer G (2002) Organic carbon at soil particle surfaces-evidence from $\mathrm{x}$ ray photoelectron spectroscopy and surface abrasion. Soil Sci Soc Am J 66:1526-1530

Anderson DW, Saggar S, Bettany JR, Stewart JWB (1981) Particle size fractionation and their use in studies of soil organic matter: I. The nature and distribution of forms of carbon, nitrogen and sulfur. Soil Sci Soc Am J 45:767-772
Baddi GA, Hafidi M, Gilard V, Revel JC (2003) Characterization of humic acids produced during composting of olive mill wastes: elemental and spectroscopic analyses (FTIR and C-13-NMR). Agronomie 23:661-666

Beare MH, Hendrix PF, Coleman DC (1994) Water-stable aggregates and organic matter fractions in conventional- and no-tillage soils. Soil Sci Soc Am J 58:777786

Beauchemin S, Hesterberg D, Beauchemin M (2002) Principal component analysis approach for modeling sulfur K-XANES spectra of humic acids. Soil Sci Soc Am J 66:83-91

Blanco-Canqui H, Lal R (2004) Mechanisms of carbon sequestration in soil aggregates. Critical Rev Plant Sci 23:481-504

Cambardella CA, Elliott ET (1993) Carbon and nitrogen distribution in aggregates from cultivated and native grassland soils. Soil Sci Soc Am J 57:1071-1076

Chenu C, Stotzky G (2002) Interactions between microorganisms and soil particles: an overview. In: Huang PM, Bollag J-M, Senesi N (eds) Interactions between Soil Particles and Microorganisms. John Wiley and Sons, New York, pp 3-40

Christensen BT (2001) Physical fractionation of soil and structural and functional complexity in organic matter turnover. Eur J Soil Sci 52:345-353

Doyle J, Doyle J (1988) Natural interspecific hybridization in eastern North American claytonia. Am J Bot 75:1238-1246

Edwards AP, Bremner JM (1967) Microaggregates in soils. J Soil Sci 18:64-73

Elliott ET, Coleman DC (1988) Let the soil work for us. Ecol Bull 39:23-32

Emerson WW (1955) Complex formation between montmorillonite and high polymers. Nature 176:461

Emerson WW (1959) Stability of soil crumbs. Nature 183:538

Filip Z, Cheshire MV, Goodman BA, Bacon JR (1988) Comparison of salt marsh humic acid with humic-like substances from the indigenous plant species Spartina alterniflora (Loisel.). Sci Total Environ 71:157-172

Filip Z, Kubat J (2003) Aerobic short-term microbial utilization and degradation of humic acids extracted from soils of long-term field experiments. Eur J Soil Biol 39:175-182

Foster RC (1981) Polysaccharides in soil fabrics. Science 214:665-667

Foster RC (1988) Microenvironments of soil microorganisms. Biol Fert Soils 6:189-203

Gauch HG, Stone EL (1979) Vegetation and soil patters in a Mesophytic forest at Ithaca, New York. Am Midl Nat 102:332-345

Gee GW, Orr D (2002) Particle-size analysis. In: Dane JH, Topp GC (eds) Methods of soil analysis. Part 4-Physical methods. SSSA, Madison, WI, pp 255-293

Geoghegan MJ, Brian RC (1948) Aggregate formation in soil. 1. Influence of some bacterial polysaccharides on the binding of soil particles. Biochem J 43:5-13

Golchin A, Oades JM, Skjemstad JO, Clarke P (1994a) Soil-structure and carbon cycling. Austr J Soil Res 32:1043-1068 
Golchin A, Oades JM, Skjemstad JO, Clarke P (1994b) Study of free and occluded particulate organic matter in soils by solid state ${ }^{13} \mathrm{C} \mathrm{CP} / \mathrm{MAS}$ NMR spectroscopy and scanning electron microscopy. Austr J Soil Res 32:285-309

Golchin A, Clark P, Oades JM, Skjemstad JO (1995) The effects of cultivation on the composition of organic matter and structural stability of soils. Austr J Soil Res 33:975-993

Greenland DJ, Lindstrom GR, Quirk JP (1961) Role of polysaccharides in stabilization of natural soil aggregates. Nature 191:1283-1284

Greenland DJ (1965) Interaction between clays and organic compounds in soils. Part 1. Mechanisms of interaction between clays and defined organic compounds. Soils Fert 28:415-425

Guggenberger G, Christensen BT, Zech W (1994) Landuse effects on the composition of organic matter in particle-size separates of soils: I. Lignin and carbohydrate signature. Eur J Soil Sci 45:449-458

Guggenberger G, Kaiser K (2003) Dissolved organic matter in soil: challenging the paradigm of sorptive preservation. Geoderma 113:293-310

Haberhauer G, Rafferty B, Strebl F, Gerzabek MH (1998) Comparison of the composition of forest soil litter derived from three different sites at various decompositional stages using FTIR-spectroscopy. Geoderma 83:331-342

Horn R, Smucker AJM (2005) Structure formation and its consequences for gas and water transport in unsaturated arable and forest soils. Soil Till Res 82:5-14

IPCC (2001) Climate Change 2001. Intergovernmental Panel on Climate Change, Working Group I: The Scientific Basis. Cambridge University Press. http:// www.ipcc.ch

Jacobsen C, Wirick S, Flynn G, Zimba C (2000) Soft X-ray spectroscopy from image sequences with sub-100 nm spatial resolution. J Microsc 197:173-184

Jandl G, Leinweber P, Schulten H-R, Eusterhues K (2004) The concentrations of fatty acids in organo-mineral particle-size fractions of a Chernozem. Eur J Soil Sci 55:459-469

Jardine PM, Weber NL, McCarthy JF (1989) Mechanisms of dissolved organic carbon adsorption on soil. Soil Sci Soc Am J 53:1378-1385

Jastrow JD (1996) Soil aggregate formation and the accrual of particulate and mineral-associated organic matter. Soil Biol Biochem 28:665-676

Kahle M, Kleber M, Torn MS, Jahn R (2003) Carbon storage in coarse and fine clay fractions of illitic soils. Soil Sci Soc Am J 67:1732-1739

Kaiser K, Eusterhues K, Rumpel C, Guggenberger G, Kögel-Knabner I (2002) Stabilisation of organic matter by soil minerals-investigations of density and particle size fractions from two acid forest soils. J Plant Nutr Soil Sci 165:451-459

Kaiser K, Guggenberger G (2003) Mineral surfaces and soil organic matter. Eur J Soil Sci 54:219-236

Kinyangi J, Solomon D, Liang B, Lerotic M, Wirick S, Lehmann J (2006) Nanoscale biogeocomplexity of the organo-mineral assemblage in soil: application of STXM microscopy and C 1s-NEXAFS spectroscopy. Soil Sci Soc Am J 70:1708-1718

Kong AYY, Six J, Bryant DC, Denison RF, van Kessel C (2005) The relationship between carbon input, aggregation, and soil organic carbon stabilization in sustainable cropping systems. Soil Sci Soc Am J 69:1078-1085

Ladd JN, Foster RC, Skjemstad JO (1993) Soil structure: Carbon and nitrogen metabolism. Geoderma 56:401434

Lal R (2003) Global potential of soil carbon sequestration to mitigate the greenhouse effect. Crit Rev Plant Sci 22:151-184

Lal R (2004) Soil carbon sequestration impacts on global climate change and food security. Science 304:16231627

Lawrence JR, Swerhone GDW, Leppard GG, Araki T, Zhang X, West MM, Hitchcock AP (2003) Scanning transmission X-ray, laser scanning, and transmission electron microscopy mapping of the exopolymeric matrix of microbial biofilms. Appl Environ Microbiol 69:5543-5554

Ledoux RL, White JL (1964) Infrared studies of the OH groups in expanded kaolinite. Science 143:244-246

Lehmann J, Liang B, Solomon D, Lerotic M, Luizao F, Kinyangi J, Schäfer T, Wirick S, Jacobsen C (2005) Near-edge X-ray absorption fine structure (NEXAFS) spectroscopy for mapping nano-scale distribution of organic carbon forms in soil: Application to black carbon particles. Global Biogeochem Cycles 19:10131025

Lerotic M, Jacobsen C, Schäfer T, Vogt S (2004) Cluster analysis of soft X-ray spectromicroscopy data. Ultramicroscopy 100:35-57

Lerotic M, Jacobsen C, Gillow JB, Francis AJ, Wirick S, Vogt S, Maser J (2005) Cluster analysis in soft X-ray spectromicroscopy: finding the patterns in complex specimens. J Electron Spectr Rel Phenom 144147C:1137-1143

Liang B, Lehmann J, Solomon D, Kinyangi J, Grossman J, O'Neill B, Skjemstad JO, Thies J, Luizão FJ, Petersen J, Neves EG (2006) Black carbon increases cation exchange capacity in soils. Soil Sci Soc Am J 70:17191730

Lichtfouse E, Chenu C, Baudin F, Leblond C, Da Silva M, Behar F, Derenne S, Largeau C, Wehrung P, Albrecht P (1998) A novel pathway of soil organic matter formation by selective preservation of resistant straightchain biopolymers: chemical and isotope evidence. Org Geochem 28:411-415

Martin JP (1945) Microorganisms and soil aggregation. I. Origin and nature of some of the aggregating substances. Soil Sci 59:163-174

Martin JP (1971) Decomposition and binding action of polysaccharides in soil. Soil Biol Biochem 3:33-41

Mayer LM, Xing BS (2001) Organic matter-surface area relationships in acid soils. Soil Sci Soc Am J 65:250258

Mayer LM, Schick LL, Hardy KR, Wagai R, McCarthy JF (2004) Organic matter content of small mesopores in sediments and soil. Geochim Cosmochim Acta 68:3863-3872 
Mikutta C, Lang F, Kaupenjohann M (2004) Soil organic matter clogs mineral pores: evidence from ${ }^{1} \mathrm{H}-\mathrm{NMR}$ and $\mathrm{N}_{2}$ adsorption. Soil Sci Soc Am J 68:1853-1862

Mikutta R, Kleber M, Torn MS, Jahn R (2006) Stabilization of soil organic matter: association with minerals or chemical recalcitrance? Biogeochem 77:25-56

Miller LM, Dumas P, Jamin N, Teillaud J-L, Miklossy J, Forro L (2002) Combining IR spectroscopy and fluorescence imaging in a single microscope: biomedical applications using a synchrotron infrared source. Rev Sci Instr 73:1357-1360

Oades JM (1988) The retention of organic matter in soils. Biogeochemistry 5:35-70

Oades JM, Waters AG (1991) Aggregate hierarchy in soils. Austr J Soil Res 29:815-828

de Oliveira AA, Mori SA (1999) A central Amazonian terra firme forest. I. High tree species richness on poor soils. Biodiv Conserv 8:1219-1244

Park EJ, Smucker AJM (2005) Erosive strengths of concentric regions within soil macroaggregates. Soil Sci Soc Am J 69:1912-1921

Rothe J, Hormes J, Schild C, Pennemann B (2000) X-ray absorption spectroscopy investigation of the activation process of Raney Nickel catalysts. J Catal 191:294-300

Santos D, Murphy SL, Taubner H, Smucker AJ, Horn R (1997) Uniform separation of concentric surface layers from soil aggregates. Soil Sci Soc Am J 61:720-724

Schimel DS, House JI, Hubbard KA (2001) Recent patterns and mechanisms of carbon exchange by terrestrial ecosystems. Nature 414:169-172

Schloesing T (1902) Etudes sur la terre vegetale. Comptes Rendus Hebdomadaires des Seances de l'Academie Sci 135:601-605

Sideri DI (1936) On the formation of structure in soil: II. Synthesis of aggregates; on the bonds uniting clay with sand and clay with humus. Soil Sci 42:461-479

Six J, Elliott ET, Paustian K, Doran JW (1998) Aggregation and soil organic matter storage in cultivated and native grassland soils. Soil Sci Soc Am J 62:13671377

Six J, Elliott ET, Paustian K (2000) Soil macroaggregate turnover and microaggregate formation: a mechanism for $\mathrm{C}$ sequestration under no-till agriculture. Soil Biol Biochem 32:2099-2103

Six J, Conant RT, Paul EA, Paustian K (2002) Stabilization mechanisms of soil organic matter: Implications for Csaturation of soils. Plant Soil 241:155-176

Six J, Bossuyt H, De Gryze S, Denef K (2004) A history of research on the link between (micro) aggregates, soil biota, and soil organic matter dynamics. Soil Till Res 79:7-31
Skjemstad JO, Janik LJ, Head MJ, McGlure SG (1993) High energy ultraviolet photo-oxidation: a novel technique studying physically protected organic matter in clay- and silt-sized aggregates. J Soil Sci 44:485-499

Sollins P, Homann P, Caldwell BA (1996) Stabilization and destabilization of soil organic matter: mechanisms and controls. Geoderma 74:65-105

Solomon D, Fritzsche F, Tekalign M, Lehmann J, Zech W (2002) Soil organic matter composition in the subhumid Ethiopian highlands as influenced by deforestation and agricultural management. Soil Sci Soc Am J 66:68-82

Solomon D, Lehmann J, Kinyangi J, Liang B, Schäfer T (2005) Carbon K-edge NEXAFS and FTIR-ATR spectroscopic investigation of organic carbon speciation in soils. Soil Sci Soc Am J 69:107-119

Stevenson FJ, Cole MA (1999) Cycles of soil: carbon, nitrogen, phosphorus, sulfur, and micronutrients. John Wiley \& Sons, New York

Sucha V, Elsass F, Eberl DD, Kuchta L, Madejova J, Gates WP, Komadel P (1998) Hydrothermal synthesis of ammonium illite. Am Mineralog 83:58-67

Tiessen H, Stewart JWB (1988) Light microscopy of stained microaggregates: the role of organic matter and microbes in soil aggregation. Biogeochem 5:312322

Tisdall JM, Oades JM (1982) Organic matter and waterstable aggregates in soils. J Soil Sci 33:141-163

Trumbore S (2000) Age of soil organic matter and soil respiration: Radiocarbon constraints on belowground C dynamics. Ecol Appl 10:399-411

USDA (1999) Soil taxonomy: a basic system of soil classification for making and interpreting soil surveys. N.R.C.S. second edition. United States Department of Agriculture, Washington, DC

Waksman SA, Martin JP (1939) The role of microorganisms in the conservation of the soil. Science 90:304-305

Wershaw RL, Pinckney DJ (1980) Isolation and characterization of clay-humic complexes. In: Baker RA (ed) Contaminants and sediments,-analysis, chemistry and biology. Ann Arbor Science Publishers, Ann Arbor, pp 207-219

Wershaw RL, Leenheer JA, Kennedy KR, Noyes TI (1996) Use of C-13 NMR and FTIR for elucidation of degradation pathways during natural litter decomposition and composting .1. Early stage leaf degradation. Soil Sci 161:667-679

Zimmerman AR, Goyne KW, Chorover J, Komarneni S, Brantley SL (2004) Mineral mesopore effects on nitrogenous organic matter adsorption. Org Geochem 35:355-375 